\title{
Sub-localisation of novel proteins with unique dynamics during assembly and maintenance of the eukaryotic flagellum
}

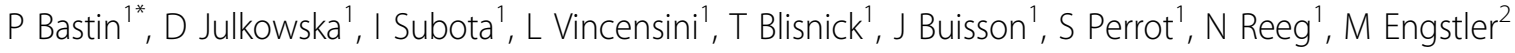 \\ From First International Cilia in Development and Disease Scientific Conference (2012) \\ London, UK. 16-18 May 2012
}

Cilia and flagella are complex organelles composed of up to 500 proteins. We have purified intact flagella from the model organism Trypanosoma brucei using mechanical shearing. Scanning and transmission electron microscopy confirmed the quality and the purity of flagella and biochemical analysis demonstrated a 15-fold enrichment of flagellar markers. Mass spectrometry investigation carried out on 5 separate experiments led to the identification of 387 proteins, 55 of which had never reported to be associated to the flagellum. 10 out of the 12 proteins investigated experimentally were indeed associated to the flagellum but turned out to localise to several sub-localisations with unique profiles: flagellar membrane, axoneme, paraflagellar rod (an extra-axonemal structure) and the adhesion zone. Two of them, termed FLAMM6 and FLAMM8 showed restricted distribution to the proximal part and to the far distal end of the axoneme, respectively. Dynamics analysis revealed that membrane proteins were incorporated by the proximal end and showed a rapid turnover whereas axonemal and PFR proteins were added to the distal end of elongating flagella but showed stable association to their structure. FLAMM6 was found only in the first half of the flagellum no matter its length, a process dependent on IFT. Finally, FLAMM8 was progressively incorporated to the elongating axoneme accumulating at the distal tip where it showed very slow turnover after flagellum formation was complete. These data highlight the existence of specific micro-domains within the eukaryotic flagellum, each with its own dynamics for assembly and turnover.

* Correspondence: pbastin@pasteur.fr

${ }^{1}$ Institut Pasteur, France

Full list of author information is available at the end of the article

Author details

${ }^{1}$ Institut Pasteur, France. ${ }^{2}$ University of Wurzburg, Germany.

Published: 16 November 2012

doi:10.1186/2046-2530-1-S1-P13

Cite this article as: Bastin et al:: Sub-localisation of novel proteins with unique dynamics during assembly and maintenance of the eukaryotic flagellum. Cilia 2012 1(Suppl 1):P13.
Submit your next manuscript to BioMed Central and take full advantage of:

- Convenient online submission

- Thorough peer review

- No space constraints or color figure charges

- Immediate publication on acceptance

- Inclusion in PubMed, CAS, Scopus and Google Scholar

- Research which is freely available for redistribution
C Biomed Central
C Biomed Central

(c) 2012 Bastin et al; licensee BioMed Central Ltd. This is an Open Access article distributed under the terms of the Creative Commons Attribution License (http://creativecommons.org/licenses/by/2.0), which permits unrestricted use, distribution, and reproduction in any medium, provided the original work is properly cited. 